\title{
Anizotropia akustyczna w utworach wapienia cechsztyńskiego (zachodnia Polska)
}

\author{
Anna Poszytek ${ }^{1}$, Pawel Lukaszewski ${ }^{1}$, Marcin Włodarczyk ${ }^{2}$
}

\begin{abstract}
Acoustic anisotropy studies in Zechstein Limestone deposits (western Poland). Prz. Geol., 69: 386-388; doi: 10.7306/2021.22
A b s t r a c t. In September 2009, gas and rock were ejected from the roof of the excavation at the Rudna copper mine of KGHM Polska Miedź S.A. The ejection occurred as a result of an unsealing of a small gas trap located a few metres above the roof of the excavation within the dolomites of the first Zechstein cyclothem (PZ1). In order to identify the nature of the reservoir rock for natural gas, microscopic observations and X-ray microtomography were performed and compared with the results of the acoustic anisotropy tests. The obtained results indicate that, based on well-recognized petrological rocks, the results of acoustic anisotropy can be successfully applied as diagnostic for the recognition of rocks of various structures, textures and porosities.
\end{abstract}

Keywords: Zechstein Limestone, acoustic anisotropy, dolomite, gas traps

Utwory wapienia cechsztyńskiego są w Polsce obiektem licznych badań ze względu na obecność w nich gazu ziemnego oraz mineralizacji miedziowej. Złoża gazu ziemnego w utworach wapienia cechsztyńskiego występuja w porowatych facjach dolomitów o charakterze rafowym, zlokalizowanych na lokalnych zrębach tektonicznych w obrębie basenu cechsztyńskiego (Karnkowski, 1999; Peryt, 1978). Utwory te są obiektem poszukiwań przemysłu naftowego. Natomiast w południowej części basenu cechsztyńskiego na pograniczu czerwonego spagowca i wapienia cechsztyńskiego występuje bogata mineralizacja miedziowa, która jest przedmiotem intensywnego rozpoznania i eksploatacji. Eksploatacja rudy miedzionośnej w kopalniach KGHM Polska Miedź S.A. odbywa się ze stropowych utworów piaskowcowych białego spagowca, lupka miedzionośnego i spagowych utworów wapienia cechsztyńskiego (Oszczepalski, Rydzewski, 1987). Jeszcze 10 lat temu eksploatacja skupiała się wyłącznie w obrębie facji platformowych wapienia cechsztyńskiego. Obecnie Zakłady Górnicze Rudna i Sieroszowice przesunęły prace górnicze na północ, udostępniając głębsze partie złoża, co spowodowało przesunięcie robót górniczych $\mathrm{z}$ utworów facji platformowej wapienia cechsztyńskiego (ponad $100 \mathrm{~m}$ miąższości) w obręb facji basenowej (do 10 m miąższości). Facje basenowe w tym rejonie są wykształcone w podobny sposób jak opisywane w literaturze facje basenowe z północnej części monokliny przedsudeckiej (Peryt, 1978; Peryt, Ważny, 1980). Są to w spagu silnie zailone madstony dolomitowe z dużą ilością materii organicznej, przechodzące ku górze w wakstony, pakstony i miejscami greinstony dolomitowe. Profil kończy się wakstonami dolomitowymi ze znaczną zawartością materiału ilastego i materii organicznej oraz w najwyższej cześci stromatolitami. W kopalni Rudna stwierdzono jednak w środkowej części profilu wapienia cechsztyńskiego występowanie poziomu pakstonów i greinstonów o miąższości ok. $0,5 \mathrm{~m}$, które charakteryzują się wysoką porowatością (do $15 \%$ ). Z tym porowatym poziomem jest związane występowanie gazu (głównie azotu), który stanowi zagrożenie gazogeodynamiczne dla kopalń miedzi (Suchan i in., 2013). We wrześniu 2009 r. w kopalni miedzi Rudna KGHM Polska Miedź S.A. doszło do wyrzutu gazu i skał ze stropu wyrobiska na skutek rozszczelnienia niewielkiej pułapki gazowej znajdującej się kilka metrów ponad stropem wyrobiska w obrębie dolomitów pierwszego cyklotemu cechsztyńskiego (PZ1) (Suchan i in., 2013). W wyniku wyrzutu w stropie wyrobiska powstała kawerna o głębokości $9 \mathrm{~m}$ i szerokości ok. $6 \mathrm{~m}$. Wyrzut skał spowodował zasypanie wyrobisk górniczych rozdrobnionym materiałem skalnym. Od tamtego wydarzenia rozpoznano szereg wystapień gazu w stropie wyrobisk górniczych w kopalni miedzi Rudna.

Dotychczasowe badania utworów wapienia cechsztyńskiego występującego w stropie wyrobisk górniczych w kopalni Rudna wykazały, że profil wapienia cechsztyńskiego w rejonie tej kopalni miedzi jest trójdzielny, a poziom zbiornikowy występuje w obrębie drugiego cyklu sedymentacyjnego (Poszytek, Suchan, 2016). Skały budujące poziom zbiornikowy mają zróżnicowaną strukturę i teksturę oraz charakteryzują się zmienną porowatością (Poszytek i in., 2018). Wyróżniono 3 typy skał zbiornikowych:

- typ 1 - dolosparyty o wysokiej porowatości $(>10 \%)$;

- typ 2 - dolosparyty o niskiej porowatości (5-10\%);

- typ 3 - dolomikryty o bardzo niskiej porowatości $(<5 \%)-$ ryc. 1 .

Wszystkie trzy typy skał występują w profilu mozaikowo, a ich zasięg jest uwarunkowany procesami diagenetycznymi (rozpuszczaniem węglanów i siarczanów i późniejsza cementacja), jakim uległy te skały (Poszytek, Suchan, 2016). Największe zagrożenie dla prac górniczych stanowią dolosparyty o wysokiej porowatości, ponieważ uwolnienie gazu z tych skał jest najgwałtowniejsze (Poszytek i in., 2020). Prawdopodobnie rozszczelnienie pułapki zbudowanej z tych skał spowodowało w 2009 r. wyrzut gazu i skał do wyrobisk górniczych.

W kopalni miedzi Rudna wykonuje się obecnie szereg otworów małośrednicowych, pełnordzeniowych w celu roz-

\footnotetext{
${ }^{1}$ Wydział Geologii, Uniwersytet Warszawski, al. Żwirki i Wigury 93, 02-089 Warszawa; anna.poszytek@uw.edu.pl; pawel.lukaszewski@uw.edu.pl

${ }^{2}$ KGHM Polska Miedź S.A., ul. Marii Skłodowskiej Curie 48, 59-301 Lubin; Marcin.Wlodarczyk@kghm.com
} 


\begin{tabular}{|c|c|c|c|}
\hline & $\begin{array}{c}\text { Dolosparyty o wysokiej porowatości } \\
\text { Dolosparite with high porosity }\end{array}$ & $\begin{array}{l}\text { Dolosparyty o niskiej porowatości } \\
\text { Dolosparite with low porosity }\end{array}$ & $\begin{array}{l}\text { Dolomikryty o bardzo niskiej porowatości } \\
\text { Dolomicrite with very low porosity }\end{array}$ \\
\hline $\begin{array}{l}\text { Obrazy } \\
\text { mikroskopowe } \\
\text { (mikroskop } \\
\text { polaryzacyjny, } \\
1 \text { nikol) } \\
\text { Microscopic views } \\
\text { (polarizing } \\
\text { microscope, single } \\
\text { nicole) }\end{array}$ & 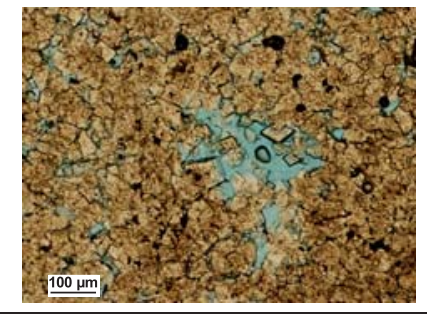 & 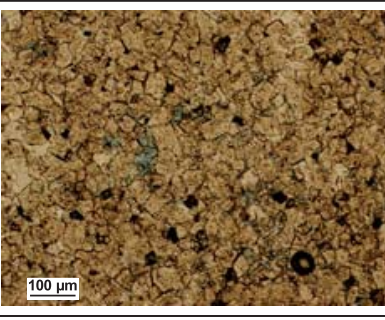 & 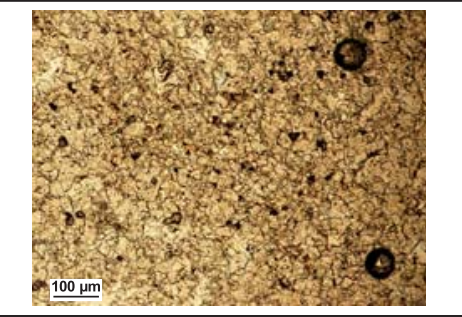 \\
\hline $\begin{array}{l}\text { Wykresy wyników } \\
\text { badań akustycznych } \\
\text { i współczynnika } \\
\text { anizotropii } \\
\text { prędkości } \\
\left.\text { fali podłużnej ( } A_{p}\right) \\
\text { Result graphs of } \\
\text { acoustic analyzes } \\
\text { and anisotropy ratio } \\
\text { of longitudinal wave } \\
\text { speed }\left(A_{p}\right)\end{array}$ & $\begin{array}{c}V_{\mathrm{ph}} \\
{[\mathrm{m} / \mathrm{s}]} \\
7000\end{array}$ & $\begin{array}{c}V_{p h} \\
{[\mathrm{~m} / \mathrm{s}]} \\
000\end{array}$ & $\begin{array}{c}V_{\mathrm{ph}} \\
{[\mathrm{m} / \mathrm{s}]} \\
7000\end{array}$ \\
\hline $\begin{array}{c}\text { Obrazy porowatości } \\
\text { na } 3 \text { prostopadłych } \\
\text { powierzchniach } \\
\text { z MCT } \\
\text { Porosity views for } 3 \\
\text { orthogonal surfaces } \\
\text { from MCT }\end{array}$ & & & \\
\hline
\end{tabular}

Ryc. 1. Wyniki obserwacji mikroskopowych, badań akustycznych i mikrotomografii rentgenowskiej dla badanych typów dolomitów Fig. 1. Results of microscopic observations, acoustic tests and X-ray microtomography for the studied types of dolomites

poznania profilu skał w stropie wyrobisk górniczych oraz ewentualnego, kontrolowanego odgazowania górotworu. Badania rdzeni z tych otworów są podstawą do określenia rodzaju potencjalnej skały zbiornikowej, co pozwala na prognozowanie dynamiki dopływu gazu do otworu i reakcji górotworu na odgazowanie (Poszytek i in., 2020). Opis struktury, tekstury i porowatości skał zbiornikowych jest możliwy na podstawie obserwacji mikroskopowych i badań laboratoryjnych, ponieważ makroskopowo utwory o zróżnicowanej porowatości są często nieodróżnialne. Jednak przygotowanie próbek do badań oraz ich wykonanie jest czaso- i kosztochłonne. Stąd bardzo przydatne są metody szybkiej identyfikacji rodzaju skał zbiornikowych, jak np. laboratoryjne badania dynamiczne (ultradźwiękowe).

\section{METODYKA BADAŃ}

Techniki ultradźwiękowe w badaniu materiałów jednorodnych są nastawione na wykrywanie uszkodzenia materiału, rozumianego jako powstawanie w nim mikropustek, mikroszczelin i mikropęknięć stanowiących nieciągłości materiału w skali mikroskopowej (Ganczarski, Skrzypek, 2013). W przypadku tak niejednorodnego materiału, jak badane dolomity, prędkość fal ultradźwiękowych zależy nie tylko od występującej w skale porowatości, ale także od jej składu mineralnego, sposobu występowania poszczególnych minerałów w skale i wielkości kryształów. Dlatego wykonując badania akustyczne, można określić wpływ wykształcenia skały na prędkość fal ultradźwię- kowych w tej skale. Najbardziej przydatna do tego celu jest analiza współczynnika anizotropii akustycznej. Mierząc prędkość fali akustycznej w próbce w dwóch prostopadłych do siebie kierunkach, otrzymujemy wartości, które wskazują, czy skała jest izotropowa akustycznie czy anizotropowa akustycznie. Korelując te wyniki z obserwacjami mikroskopowymi, można określić, jak struktura, tekstura i porowatość skały wpływają na anizotropię akustyczną badanych skał.

Z rdzeni z 8 otworów wiertniczych wykonanych w stropie wyrobisk górniczych w kopalni miedzi Rudna pobrano próbki z poziomu zbiornikowego nasyconego gazem. Z rdzeni wiertniczych o średnicy ok. $3 \mathrm{~cm}$ wycięto 8 próbek o wysokości $6 \mathrm{~cm}$. Na wszystkich próbkach, bezpośrednio po ustaleniu ich wymiarów geometrycznych, przeprowadzono badania dynamiczne (ultradźwiękowe) na Wydziale Geologii Uniwersytetu Warszawskiego. Do pomiarów zastosowano defektoskop ultradźwiękowy DEF8USB z dedykowanym do tego celu oprogramowaniem firmy M. Lew LAB oraz głowice nadawczą i odbiorczą o częstotliwości sygnału 0,5 MHz. Sprawdzono, że dla zastosowanej częstotliwości próbki spełniają warunek nieograniczoności ośrodka, tzn. że ich rozmiary są trzykrotnie większe niż długość propagowanej fali, a także nie występuje dyspersja fali.

Pomiary prowadzono metodą przejścia polegającą na bezpośrednim pomiarze czasu przechodzenia impulsu dźwiękowego przez próbkę walcową umieszczoną między głowicą nadawczą a odbiorczą. Pomiary fali podłużnej wykonywano w kierunku prostopadłym $\left(V_{p d}\right)$ i równo- 
ległym $\left(V_{p h}\right)$ do osi próbki. Prędkość fali podłużnej dla różnych kierunków badania wyznaczono wg wzorów:

$$
V_{p d}=\frac{d}{t_{d}} \quad[\mathrm{~m} / \mathrm{s}]
$$

oraz

$$
V_{p h}=\frac{h}{t_{h}} \quad[\mathrm{~m} / \mathrm{s}]
$$

Na podstawie pomiaru prędkości fali podłużnej w kierunku prostopadłym i równoległym do osi próbki ustalono współczynnik anizotropii prędkości fali podłużnej $\left(A_{p}\right)$, zgodnie $\mathrm{z}$ formułą:

$$
A_{p}=\frac{V_{p h}}{V_{p d}}
$$

\section{WYNIKI BADAŃ I DYSKUSJA}

Na podstawie otrzymanych wyników współczynnika anizotropii prędkości fali podłużnej $\left(A_{p}\right)$ stwierdzono, że wartości anizotropii akustycznej próbek bardzo dobrze korelowały się z obserwacjami mikroskopowymi (ryc. 1):

- dolosparyty o wysokiej porowatości charakteryzowały się wysoką anizotropią akustyczną $\left(A_{p} 0,55-0,59\right)$. Mają na to wpływ wysoka porowatość i sposób występowania cementów, które występują blokowo, tworząc w skale strefy pozbawione porowatości. Wprawdzie w badaniach mikroskopowych nie zaobserwowano kierunkowości ułożenia cementów oraz porowatości, jednak wyniki badań porowatości z mikrotomografii rentgenowskiej (Poszytek i in., 2018) pokazały, że porowatość w tych skałach jest wyższa w płaszczyźnie poziomej niż w pionowej;

- dolosparyty o niskiej porowatości charakteryzowały się niską anizotropią akustyczną $\left(A_{p} 0,84-0,90\right)$. Mają na to wpływ cementy anhydrytowe i węglanowe, które w dużym stopniu wypełniają przestrzeń międzykrystaliczną tych dolosparytów, redukując znacznie ich porowatość. Obrazy porowatości z badań mikrotomografii rentgenowskiej (Poszytek i in., 2018) pokazują, że porowatość w płaszczyźnie poziomej i pionowej w tych skałach jest bardzo zbliżona, stąd badane dolosparyty charakteryzują się niską anizotropią akustyczną;

- dolomity mikrytowe o bardzo niskiej porowatości charakteryzowały się bardzo niską anizotropią akustyczną $\left(A_{p}\right.$ 0,96-0,98). Ma na to wpływ regularne występowanie bardzo drobnych porów, których ilość jest zbliżona w pła- szczyźnie poziomej i pionowej (Poszytek i in., 2018). Występowanie jednolitej matrycy skalnej w postaci dolomikrytu dodatkowo wpływa na bardzo niską anizotropowość akustyczną tych skał.

Uzyskane wyniki wskazuja, że bazując na dobrze rozpoznanych petrologicznie skałach, można z dużym powodzeniem stosować wyniki anizotropii akustycznej jako diagnostyczne dla rozpoznania skał o zróżnicowanym wykształceniu. Jest to szczególnie przydatne w przypadku konieczności szybkiego rozpoznania skał, których cechy makroskopowe nie pozwalają nawet na szacunkową ocenę np. porowatości. W przypadku dolomitów ze stropu wyrobisk kopalni miedzi Rudna jest to kluczowy problem dla zapewnienia bezpieczeństwa prowadzenia robót górniczych. Badania akustyczne są prostym i tanim narzędziem, na podstawie którego można prowadzić szeroko zakrojone badania przesiewowe próbek, które mogą ułatwić i przyśpieszyć określenie charakteru skały zbiornikowej.

Autorzy dziękują recenzentom: prof. Katarzynie Jarmołowicz-Szulc i prof. Tadeuszowi Perytowi, za cenne uwagi i komentarze do artykułu.

\section{LITERATURA}

KARNKOWSKI P.H. 1999 - Origin and evolution of the Polish Rotliegend Basin. Państw. Inst. Geol., Spec. Pap., 3: 1-93.

GANCZARSKI A., SKRZYPEK J. 2013 - Mechanika nowoczesnych materiałów. PKrak., Kraków.

OSZCZEPALSKI S., RYDZEWSKI A. 1987 - Paleogeography and sedimentary model of the Kupferschiefer in Poland. [W:] Peryt T.M. (red.), The Zechstein Facies in Europe. Lecture Notes in Earth Sci., 10: 189-205.

PERYT T.M. 1978 - Sedimentology and paleoecology of the Zechstein Limestone (Upper Permian) in the Fore-Sudetic area (western Poland). Sediment. Geol., 20: 217-243.

PERYT T.M., WAŻNY H. 1980 - Microfacies and geochemical development of the basin facies of the Zechstein Limestone (Ca1) in western Poland. Contribut. Sediment., 9: 279-306

POSZYTEK A., SUCHAN J. 2016 - A tight gas reservoir in the basinal facies of the Upper Permian Ca1 in the southwestern Zechstein Basin, Poland. Facies, 62; https://doi.org/10.1007/s10347-015-0453-5

POSZYTEK A., DUDEK L., ROŻEK R. 2018 - Presence of natural gas in basinal facies of the Zechstein Limestone in a copper mine in SW Poland. J. Petrol. Geol., 41: 67-83.

POSZYTEK A., RYBAK-OSTROWSKA B., ŁUKASZEWSKI P., WŁODARCZYK M. 2020 - Gas traps stability in the Zechstein Limestone from the Rudna Copper Mine (SW Poland). Inter. J. Earth Sci., 109: 439-463.

SUCHAN J., ROŻEK R., HRYCIUK A. 2013 - Warunki sedymentacji i zróżnicowanie facjalne Wapienia Cechsztyńskiego a zagrożenie gazowe i gazogeodynamiczne w O/ZG Rudna, KGHM Polska Miedź S.A. V Konferencja Sedymentologiczna POKOS 5'2013.

Praca wpłynęła do redakcji 23.04.2021 r.

Akceptowano do druku 14.05.2021 r. 